\title{
Effect Test Stimulant of Curcuma Rhizome Infusion (Curcuma xanthorrhiza Roxb.) On Male Mice Swiss Strain
}

\author{
Neni Lugki Nian Tary and Tanti Azizah Sujono \\ Fakultas Farmasi, Universitas Muhammadiyah Surakarta, \\ Jl. A. Yani Tromol Pos I, Pabelan, Surakarta 57102
}

\begin{abstract}
The used of plants efficacious as medicines in the prevention of health problems had been known for a long time the Indonesian people. The utilization of plants as medicine was based on the experience passed down from generation to generation. The used of traditional medicines relatively favored by the people, the underlying factor are traditional medicines have less side effects than the modern medicines if used appropriately. Curcuma (Curcuma xanthorrhiza Roxb.) used as refreshment which had stimulant effect.. Stimulant was a substance that can stimulated the central nervous system which can speed up the processes in the body and minimize fatigue. Need to research the effects of stimulant infusion of curcuma rhizome. The research was conducted experimental methods pre-test and post-test. Twenty-five male mice Swiss strain used as experimental animals, which are divided into five groups, positive control (caffeine 100mg / $\mathrm{kg} \mathrm{BW}$ ), negative control (distilled water $0,5 \mathrm{ml} / 20 \mathrm{~g} \mathrm{BW}$ ), infusion of curcuma dose I (2.5 $\mathrm{g} / \mathrm{kg} \mathrm{BW}$ ), dose $I I(5 \mathrm{~g} / \mathrm{kg} \mathrm{BW})$, and dose III $(10 \mathrm{~g} / \mathrm{kg} \mathrm{BW})$ respectively. Animal experiments tested using methods Natatory Exhaustion and treated with oral route. The effects of stimulant tired was calculated the time difference before and after treatment. The data obtained were analyzed non-parametric statistical tests, it's Kruskal Wallis and Mann Whitney with a 95\% confidence level. Infuse curcuma rhizome had the stimulant effect, the effect was obtained by increased the dose. At doses of $2.5 \mathrm{~g} / \mathrm{kg} \mathrm{BW,} 5 \mathrm{~g} / \mathrm{kg} \mathrm{BW}$, and $10 \mathrm{~g} / \mathrm{kg} \mathrm{BW}$ was provide a stimulant effect respectively by 2.82 minutes, 3.71 minutes and 4.94 minutes. Stimulant effect dose II and III had a greater effect than the positive control $(p<0,05)$, the dose I had similar effect compare with control positive $(p>0,05)$.
\end{abstract}

Keywords: infusion of curcuma rhizome, stimulant effect, Natatory Exhaustion, male mice

\section{Introduction}

The use of plants efficacious as medicines in the prevention of health problems had been known for a long time the Indonesian people. The utilization of plants as medicine was based on the experience passed down from generation to generation. The used of traditional medicines relatively favored by the people, the underlying factor were traditional medicines had less side effects than the modern medicines if used appropriately (Sari, 2006). The other reason because prices of modern drugs more expensive, so purchase of modern drug weakened. Replied many complaints several pharmaceutical industries started to seek the most of effective alternative by look for back to nature as had done of developed countries which applyed the concept (Kartikasari et al., 2011). WHO recommend for maintenance of public health, prevention and treatment the disease use traditional medicine. Renewal the global strategy of traditional medicine should done in order to be used safely and effectively (WHO, 2008).

Stimulant was a substance that can stimulate the central nervous system which can speed up the processes in the body, can increase the physical and mental abilities, and improve concentration, so that it can make people better prepared, and minimize the fatigue (Sujatno, 2001). Stimulant was an active compound which also influence the overall body organ (Katzung, 2001). Generally public used the stimulants in the form of a supplement drinks with the aim to increased energy and reduced fatigue due to physical working (Setiabudy, 2005).

Now, the diversity of plants in Indonesia efficacious as medicine had not been used optimally. This is because the low of public knowledge about medicinal plants (Kartikasari et al, 2011). One of them was used of curcuma as a stimulan. In this study simplicia made in the pharmaceutical of curcuma infusion, 
but many person use curcuma in an infusion (Badan POM RI, 2005), But so far the stimulant efficacy of curcuma based only on empirical experience, so the need study to obtain scientific data about its effect as a stimulant.

\section{Research Methodology}

This study classified in the category of experimental research with pre-test and posttest.

\section{Material and Equipment}

Infuse of Curcuma rhizome (Curcuma xanthorrhiza Roxb), male mice Swiss strain (20-40 g, 2-3 months). The solvent used distilled water, caffeine $0.4 \% \mathrm{w} / \mathrm{v}$ as a positive control. The tools include electric stove, pans infuse, analytical balance, filter paper, rod stirrer, and glass tools used to make the infusion. Test the stimulant were used tools such as, injection syringes, syringe for orally, stopwatch, thermometer, reservoir, scales and hair dryer.

\section{a. Preparation of Simplicia}

Curcuma rhizome washed under running water, then cuted into smaller parts, then dried by means inserted into the dryer cabinet with a temperature of $47^{\circ} \mathrm{C}$.

\section{b. Preparation of Curcuma Infusion}

Infusion of curcuma made into several concentrations $10 \%, 20 \%, 40 \%$. It made by weighted the dry simplicia according to the concentration. Simplicia weighted each 10 grams, 20 grams and 40 grams, then it boiled with $100 \mathrm{ml}$ of distilled water using a drip pan. Extra water is used $2 \mathrm{x}$ the weight of each weighted ingredients, extra water used was 20 $\mathrm{mL}$ for a weight of 10 grams, $40 \mathrm{ml}$ for the weight of 20 grams, and $80 \mathrm{ml}$ for a weight of 40 grams. Simplicia boiled for 15 minutes begins when the temperature reached $90^{\circ} \mathrm{C}$ while stirred. Contains essential oils of curcuma, then filtered after cold (Depkes RI, 1979).

\section{c. Preparation of caffein solution stock}

Caffeine weighed 40,0 mg, then dissolved use distilled water in the flask until $10 \mathrm{~mL}$. The dose used was $100 \mathrm{mg} / \mathrm{kg}$ (Turner, 1965).

\section{d. Infuse Stimulant Effect of Curcuma test}

Animal test used in this study amounted to 25 male mice Swiss strain. Test animals were divided into 5 groups. Each treatment consisted of 5 mice. The treatment consisted of a positive control using caffeine of $100 \mathrm{mg} / \mathrm{kgBW}$ and negative controls was used distilled water $0,5 \mathrm{ml} / 20 \mathrm{mgBW}$, and infuse ginger rhizome was consist of three levels, lowdose, medium-dose and high dose. The classification is :

Group I : Positive control used caffein solution with concentration $0.4 \%$, a dose of $100 \mathrm{mg} / \mathrm{kg}$ BW orally (Turner, 1965).

Group II : Negative control used distilled water $0,5 \mathrm{ml} / 20 \mathrm{mgBW}$ orally.

Group III : Curcuma rhizome infusion with dose of $2.5 \mathrm{~g} / \mathrm{kgBW}$, orally.

Group IV : Curcuma rhizome infusion with dose of $5 \mathrm{~g} / \mathrm{kgBW}$, orally.

Group V : Curcuma rhizome infusion with dose of $10 \mathrm{~g} / \mathrm{kgBW}$, orally.

The animals were given a test before treatment included in the reservoir, after the onset of fatigue was characterized by animals test let his head under water for more than 7 seconds (Turner, 1965), then the animals test raised and recorded tired time (t1). Animals test rested for 30 minutes and dried before being treated. The treatment was done orally, the maximum limit provision volume in mice for the oral administration of 1,0 $\mathrm{ml}(\mathrm{MOH}$, 
1993), and then treated orally and wait for 30 minutes, a time of orientation in order to advance the preparation of drug absorbed (Aznam, 2009), then swam and noted the tired time (t2). The tired time difference was calculated from before and after treated $(\mathrm{t} 2-$ t1).

Tired time difference before and after the treatment was given the test data stimulant effect. This data was obtained from all treatment of all groups of test animals.

\section{Data Analysis}

Quantitative data obtained is the result of the time difference Tired before and after the animals test treated. All data have been collected statistical testing, to determine the data obtained normally distributed or not so tested with Shapiro Wilk method, where as to determined whether or not a homogeneous data obtained so tested use Levene-test.

Data obtained normally distributed, but not homogeneous thus performed data was used non-parametric statistical tests. Tests using Kruskal Wallis, because the data obtained significantly different so do the methods Mann Whitney test with $95 \%$ confidence level.

\section{Result and Discusion}

\section{Extraction of Curcuma Rhizhoma}

Extraction method used this study was infundation, which was one method that was carried out in a manner extraction for found the active compounds using water. The advantages from this method, among others, the equipment was used quite simple and easy to use, and the extraction method process cheapest.

\section{Animals Endurance Test}

Orientation test of animal endurance aimas to determined how long it taken the animals test to restore his stamina as the first time before the animals swam. Rest time wasused to minimize error in the base line in 24 hours. On this test used 3 animals that swam for 3 days in a row. The test results orientation breaks the data obtained as in table 1

Tabel 1. The results of animals orientation endurance test for 24 hours in a span of 3 days

\begin{tabular}{cccc}
\hline Animal number & t 1 (menit) & t 2 (menit) & t 3 (menit) \\
\hline 1 & 4,37 & 3,96 & 4,18 \\
2 & 4,80 & 5,28 & 4,18 \\
3 & 3,12 & 4,95 & 4,03 \\
Average & 4,09 & 4,73 & 4,13 \\
SD & 0,87 & 0,68 & 0,08 \\
\hline
\end{tabular}

Table 1 shown the data obtained continued statistical test method is paired t test with a level of $95 \%$ and get $p$ values $>0,05$, it was no significant difference of the third test time of tired with 24 -hour rest period. It can be concluded that energy of animals have returned the same as at the time of animals test before swam with a break for 24 hours.

\section{The Results of curcuma infusion stimulant effects test}

Natatory Exhaustion method were used in this study because the method was a pharmacological screening methods that could be are used to determine the stimulant effects of a drug or preparation that can activate the body's motor coordination and give the effect of increased work capacity and to minimize fatigue. The results obtained from this method is the data increments Tired in each treatment group. Tired first time (t1) was time tired prior to the treatment, while the second time fatigue (t2) was the time Tired after test animals treated. Results increments Tired $(\Delta t)$ was the data obtained from the difference between Tired first time (t1) and a Tired second (t2). Data from the addition of a Tired test animals presented in table 2. 
Table 2. Data of tired time after administration infuse ginger rhizome

\begin{tabular}{|c|c|c|c|c|c|}
\hline Group & No & t1 (menit) & t2 (menit) & $\Delta \mathrm{t}$ & SD \\
\hline \multirow{5}{*}{$\begin{array}{l}\text { Positif control } \\
\quad(\text { caffein- } \\
100 \mathrm{mg} / \mathrm{kgBW})\end{array}$} & 1 & 11,38 & 12,62 & 1,24 & \multirow{5}{*}{$1,85 \pm 0,83$} \\
\hline & 2 & 7,58 & 9,15 & 1,57 & \\
\hline & 3 & 8,35 & 9,75 & 1,40 & \\
\hline & 4 & 6,38 & 8,12 & 1,74 & \\
\hline & 5 & 4,53 & 7,82 & 3,29 & \\
\hline \multirow{5}{*}{$\begin{array}{c}\text { Negatif con- } \\
\text { trol (Aquadest } \\
0,5 \mathrm{~mL} / 20 \mathrm{~g}- \\
\mathrm{BW})\end{array}$} & 1 & 4,22 & 5,58 & 1,36 & \multirow{5}{*}{$-1,23 \pm 1,65$} \\
\hline & 2 & 6,18 & 5,58 & $-0,60$ & \\
\hline & 3 & 6,05 & 4,15 & $-1,90$ & \\
\hline & 4 & 6,68 & 4,40 & $-2,28$ & \\
\hline & 5 & 6,50 & 3,78 & $-2,72$ & \\
\hline \multirow{5}{*}{$\begin{array}{l}\text { Curcuma rhi- } \\
\text { zome infusion } \\
2,5 \mathrm{~g} / \mathrm{kgBW}\end{array}$} & 1 & 5,37 & 8,97 & 3,60 & \multirow{5}{*}{$2,82 \pm 1,02$} \\
\hline & 2 & 5,65 & 7,02 & 1,37 & \\
\hline & 3 & 6,50 & 8,65 & 2,15 & \\
\hline & 4 & 5,67 & 9,38 & 3,71 & \\
\hline & 5 & 4,07 & 7,32 & 3,25 & \\
\hline \multirow{5}{*}{$\begin{array}{l}\text { Curcuma rhi- } \\
\text { zome infusion } \\
5 \mathrm{~g} / \mathrm{kgBW}\end{array}$} & 1 & 5,70 & 8,63 & 2,93 & \multirow{5}{*}{$3,71 \pm 0,99$} \\
\hline & 2 & 5,50 & 9,73 & 4,23 & \\
\hline & 3 & 4,42 & 9,38 & 4,96 & \\
\hline & 4 & 7,13 & 9,65 & 2,52 & \\
\hline & 5 & 3,95 & 7,85 & 3,90 & \\
\hline \multirow{5}{*}{$\begin{array}{l}\text { Curcuma rhi- } \\
\text { zome infusion } \\
10 \mathrm{~g} / \mathrm{kgBW}\end{array}$} & 1 & 3,43 & 6,18 & 2,75 & \multirow{5}{*}{$4,94 \pm 2,06$} \\
\hline & 2 & 3,60 & 7,35 & 3,75 & \\
\hline & 3 & 3,23 & 7,18 & 3,95 & \\
\hline & 4 & 2,93 & 10,42 & 7,49 & \\
\hline & 5 & 3,43 & 10,18 & 6,75 & \\
\hline
\end{tabular}

This study was conducted with the aim of knowing the possible cause and effect of various treatment groups. The groups treated with ginger rhizome and infuse positive control than the negative control group.

Animals test was swam Natatory Exhaustion method can show the effect of the preparation on the coordination of movement between before and after treatment (Aznam, 2009). Animal physical endurance test in activity is different, it can be influenced among other things test animals age, the older the test animals, the ability to move a muscle for defense condition is also declining. The ability of each test animals in absorbing preparations also differ, depending on the health condition of the animal itself.

The data result of stimulant effect test from positive control, negative control, has activities in increased metabolism and can and provision infuse ginger rhizome with 3 different dose levels can be seen in Table 2. In accordance with the data shown in Table 2 shows the addition of a Tired at each treatment group, except in the control group negative. Extension of time Tired indicated by the before treatment and after being treated.

Time tired obtained after treatment is greater than the time tired before treatment, except in the negative control no additional time tired. Negative controls was distilled water did not show any additional time tired, which means distilled water has no stimulant activity to prolong tired test animals. In contrast to the positive control that used caffeine, the data obtained indicate the presence of extratime tired after the treatment, because caffeine difference in time when the test animals Tired 
reduce fatigue. The same was also indicated in the treatment group using the infusion of ginger rhizome with 3 different dose levels.

The data have been obtained were tested with statistical methods. Testing is done by using parametric statistical methods ShapiroWilk test for reasons the amount of data that is processed was less than 30. From the ShapiroWilk test obtained significance value of 0.275 in order to obtain results $\mathrm{p}>0.05$, which means the data processing result normally distributed, but the data processing with the test Levene test for homogeneity test result of $0.034(p<0.05)$, so that the data processing show results that are not homogeneous. Not homogeneous due to the data obtained, the data and then tested with a non-parametric statistical method using the Mann-Whitney test. Results of Mann-Whitney test can be seen in Table 3.

Table 3. Data statistical test by Mann-Whitney method

\begin{tabular}{cccccc}
\hline group & I & II & III & IV & V \\
\hline I & $\mathbf{0 , 0 1 6}$ & 0,175 & $\mathbf{0 , 0 2 8}$ & $\mathbf{0 , 0 1 6}$ \\
II & & $\mathbf{0 , 0 0 9}$ & $\mathbf{0 , 0 0 9}$ & $\mathbf{0 , 0 0 9}$ \\
III & & & 0,175 & $\mathbf{0 , 0 4 7}$ \\
IV & & & & 0,465 \\
V & & & &
\end{tabular}

information: group I: Positif control (kafein 100mg/kgBB), group II: Negatif control (aquadest 0,5mL/20g BB), group III: Curcuma rhizome infusion $2,5 \mathrm{~g} / \mathrm{kgBW}$, group III: Curcuma rhizome infusion $5 \mathrm{~g} / \mathrm{kgBW}$, group IV:

Curcuma rhizome infusion $10 \mathrm{~g} / \mathrm{kg} \mathrm{BW}$

From the data presented in Table 3 indicates that each treatment group using the infusion of ginger rhizome has a significant difference to the negative control group with $\mathrm{p}<0,05$, which means that infuse a dose of ginger rhizome $2,5 \mathrm{~g} / \mathrm{kg} \mathrm{BW}, 5 \mathrm{~g} / \mathrm{kgBW}$ and $10 \mathrm{~g} / \mathrm{kgBW}$ was able to increased the time Tired, while the treatment using infusion of ginger rhizome at 3 different dose levels also have a significant difference to the positive control because the obtained values $(\mathrm{p}<0,05)$, which means infuse a dose of $5 \mathrm{~g} / \mathrm{kgBW}$ and $10 \mathrm{~g} / \mathrm{kgBW}$ was able to increase the time Tired is greater than the positive control, except at doses of $2,5 \mathrm{G} / \mathrm{kg}$ obtained values $(\mathrm{p}>0,05)$, which means the effect was equivalent to the positive control.

The average difference time Tired throughout the test animals that had been treated infuse ginger rhizome shown in Figure 1.

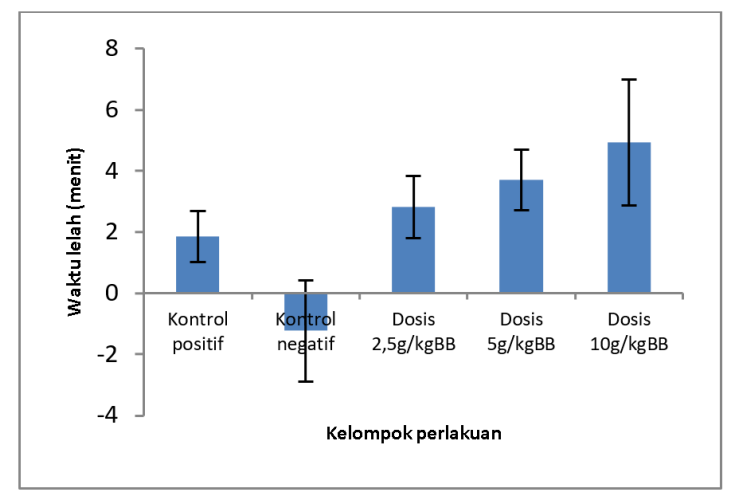

Figure 1. Histogram stimulant effect infuse of curcuma rhizome

Figure 1 shown it could observed if the infusion of ginger rhizome has a stimulant effect, except in the negative control was not very aesthetically their stimulant effect. The histogram shows that the stimulant effect increased with the increasing dose. 
Based from previous study, qualitative analysis ginger rhizome was contain alkaloid compounds and triterpennoid (terpenoids) were dominant (Hayani, 2006). The content of chemical compounds in ginger were believed to had stimulant effects were alkaloids and triterpennoid. Active compound class of alkaloids and terpenoids were responsible for the increased in stimulant activity in test animals male mice Swiss strain (Nuria, 2013).

\section{Conclusion}

The results of research conducted as well as the discussion that had been described can be deduced that infuse a dose of ginger rhizome $2.5 \mathrm{~g} / \mathrm{kg} \mathrm{BW} ; 5 \mathrm{~g} / \mathrm{kg} \mathrm{BW} ; 10 \mathrm{~g} / \mathrm{kgBW}$ had a stimulant effect on the male mice Swiss strain.

\section{Advice}

This study needed regarding any compounds contained in curcuma rhizome were responsible for providing stimulant effect.

\section{Acknowledgment}

The author acknowledge Pharmacy Faculty Muhammadiyah University of Surakarta for supporting the research equipment and all of facility.

\section{References}

Aznam, N., 2009, Stimulant Effect of Pasak Bumi (Eurycoma longifolia. Jack) Root Powder by Natatory Exhaustion at Male Mice, Isstec

Badan POM RI, 2005, Info POM, 3, Jakarta, Badan POM Republik Indonesia

Depkes RI, 1979, Farmakope Indonesia Edisi III, 63-67, Jakarta, Departemen Kesehatan Republik Indonesia

Depkes RI, 1993, Penampisan Farmakologi, Pengujian Fitokimia dan Pengujian Klinik, 19-21, Departemen Kesehatan Republik Indonesia, Jakarta

Hayani, E., 2006, Analisis Kandungan Kimia Rimpang Temulawak, Pusat Penelitian dan Pengembangan Peternakan, 309-312

Kartikasari, R., Hikmat, A., Zuhud, E. A. M., Siswoyo., \& Sandra, E., 2011, Revitalisasi Konservasi Tumbuhan Obat Keluarga (TOGA) Guna Meningkatkan Kesehatan dan Ekonomi Keluarga Mandiri di Desa Contoh Lingkar Kampus IPB Darmaga Bogor, Jurnal Ilmu Pertanian Indonesia, 16 (2), 71-80

Katzung, B., 2001, Farmakologi Dasar dan Klinik, Salemba Medika, Jakarta

Nuria, M. C., Anas, Y., Puspitasari, N., 2013, Aktivitas StimulansiaEkstrak Etanol Bunga dan Daun Cengkeh (Syzygium aromaticum (L) Merr. \& Perry.) pada Mencit Jantan Galur Swiss Beserta Identifikasi Golongan Senyawa Aktifnya, Jurnal Ilmu Farmasi dan Farmasi Klinik, 10 (1), 13-22

Sari, L. O. R. K., 2006, Pemanfaatan Obat Tradisional dengan Pertimbangan Manfaat dan Keamanannya, Majalah Ilmu Kefarmasian, 3 (1), 01-07

Sujatno, M., 2001, Pengaruh Penggunaan Doping Terhadap Penampilan Atlet pada Pekan Olah Raga Nasional XIV/1996 dan South East Asian Games XIX/1997 di Jakarta, JKM, 1 (1), $32-38$

Turner, R. A., 1965, Screening Methods in Pharmacology, Volume, Hal 76-77, New York and London, Academic Press

WHO, 2008, Tradisional Medicine, 11-12, Geneva, World Health Organization 